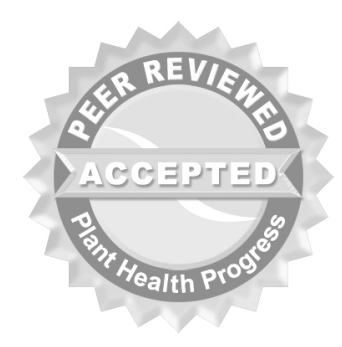

(C) 2010 Plant Management Network.

Accepted for publication 23 August 2010. Published 14 September 2010.

\title{
Cover Crops of Hybrid Common Vetch Reduce Fusarium Wilt of Seedless Watermelon in the Eastern United States
}

Anthony P. Keinath, Professor, and Richard L. Hassell, Associate Professor, Clemson University, Coastal Research and Education Center, Charleston, SC 29414; Kathryne L. Everts, Professor, University of Maryland, Lower Eastern Shore Research and Education Center, Salisbury, MD 21801 and University of Delaware, Research and Education Center, Georgetown, DE 19947; and Xin-Gen Zhou, Assistant Professor, Texas A \& M University System, AgriLife Research and Extension Center, Beaumont, TX 77713

Corresponding author: A. P. Keinath.tknth@clemson.edu

Keinath, A. P., Hassell, R. L., Everts, K. L., and Zhou, X.-G. 2010. Cover crops of hybrid common vetch reduce Fusarium wilt of seedless watermelon in the eastern United States. Online. Plant Health Progress doi:10.1094/PHP-2010-0914-01-RS.

\begin{abstract}
Fusarium wilt of watermelon, caused by Fusarium oxysporum f. sp. niveum races $0,1,2$, or 3, is found throughout the eastern United States. Most seedless (triploid) watermelon cultivars are susceptible to all races. In previous studies in Maryland, winter cover crops of hairy vetch (Vicia villosa) reduced Fusarium wilt. The objectives of this study were to compare 'Cahaba White' hybrid common vetch (V. sativa $\times$ V. cordata) to hairy vetch for suppression of Fusarium wilt in South Carolina and Maryland. Cover crops of the two vetches and rye (the control) were seeded in fall 2006 and 2007 in fields naturally infested with a mixture of races 1 and 2 in South Carolina and Maryland. In the spring after incorporating the cover crop biomass, seedless watermelons cv. Sugar Heart (susceptible) or Revolution (moderately resistant to race 1 ) were transplanted into subplots within each cover crop whole plot. 'Cahaba White' vetch was as effective as hairy vetch in reducing incidence of Fusarium wilt. Both vetch varieties reduced wilt incidence by approximately the same degree with the susceptible as with the moderately resistant cultivar. In general, the moderately resistant cultivar yielded more fruit (by weight) than the susceptible cultivar.
\end{abstract}

\section{I ntroduction}

Fusarium wilt is an important soilborne disease of watermelon (Citrullus lanatus var. lanatus) in the mid-Atlantic and southeastern United States (16). Frequently cropping fields to watermelon selects for the specialized form of Fusarium oxysporum, F. oxysporum f. sp. niveum (FON), that attacks watermelon (8). Fusarium wilt kills individual vines or whole plants, directly reducing the number of fruit produced. In a survey conducted in 2000 in Maryland and Delaware, FON was widely distributed throughout production fields (17). Approximately half of the surveyed fields had levels of the pathogen high enough to cause $50 \%$ wilt incidence on a highly susceptible cultivar, such as Sugar Baby.

Race 2, a highly aggressive race of FON, is an emerging problem throughout watermelon production areas in the eastern United States. Prior to 2000, this race was limited to Texas, Oklahoma, and Florida (12). It has since been found in five additional states: Maryland (17), Delaware (17), Indiana (5), Georgia (3), and South Carolina (9). Although race 1 is the most prevalent race in the midAtlantic region, 24\% of the fields surveyed in Maryland and Delaware were infested with race 2 (17). In South Carolina, race 2 was found in all fields sampled (9). Recently, isolates belonging to the new race 3 were identified in Maryland (22). Because neither diploid seeded nor triploid seedless cultivars have resistance to races 2 or 3, watermelon crop losses due to Fusarium wilt are increasing. 
Management of Fusarium wilt was achieved in the past through a

combination of long crop rotations [up to 12 years in some cases (13)], and host resistance in hybrid diploid, seeded cultivars $(2,14)$. However, the effectiveness of host resistance is dependent on which races of the pathogen are present. A few triploid seedless cultivars have a moderate level of resistance to race 1 $(11,21)$. However, most of these cultivars are not grown commercially for various reasons. For example, because 'Seedless Sangria' can be mistaken by produce buyers and consumers for the seeded cultivar 'Sangria,' 'Seedless Sangria' is no longer available.

A new management tactic for Fusarium wilt is the production of watermelon following a fall-planted hairy vetch (Vicia villosa) cover crop that is killed and turned into the soil in the spring (18). Incorporating hairy vetch in the spring prior to transplanting watermelon reduced incidence of Fusarium wilt and increased yields in Maryland by $45 \%$, which was as good as control with methyl bromide or Telone C-35 fumigation. Watermelon yields after a hairy vetch cover crop increased from 35\% to 65\% compared to the control treatment, again, as good as the fumigants (18). In addition, hairy vetch was effective against both race 1 and 2 of FON. One problem with this method of control is that hairy vetch and watermelon are hosts of Southern root-knot nematode (Meloidogyne incognita), the predominant root-knot species in the South. A hybrid cultivar of common vetch, 'Cahaba White' (V. sativa $\times \mathrm{V}$. cordata), that is resistant to Southern root knot nematode may provide similar benefits as hairy vetch without the risk of increasing populations of $\mathrm{M}$. incognita $(7,15)$.

The objectives of this study were to: (i) compare 'Cahaba White' hybrid common vetch to hairy vetch for suppression of Fusarium wilt; (ii) compare vetch cover crop performance in South Carolina and Maryland; (iii) determine if vetch cover cropping improved control of Fusarium wilt with a cultivar moderately resistant to race 1 planted in soil infested with a mixture of races; and (iv) calculate the economic costs and returns of vetch cover cropping in seedless watermelon production.

\section{Comparing 'Cahaba White' to Hairy Vetch for Suppression of Fusarium Wilt}

The experiments were done in 2006 to 2007 and 2007 to 2008 in two fields of Young's loamy fine sand at Clemson University's Coastal Research and Education Center, Charleston, SC, and in two fields of Norfolk "A" loamy sand at the University of Maryland's Lower Eastern Shore Research and Education Center, Salisbury, MD. All four fields had previously been documented to contain races 1 and 2 of FON $(9,17)$. The experimental design was a split-plot with six replications in South Carolina and four replications in Maryland. Whole plots consisted of three winter cover crop treatments: hybrid common vetch 'Cahaba White,' hairy vetch (cultivar unspecified), and rye (Secale cereale). Subplots consisted of two triploid watermelon cultivars with different levels of wilt resistance, 'Sugar Heart' and Revolution,' susceptible and moderately resistant to Fusarium wilt race 1, respectively (19). 'Sugar Heart' was selected as the susceptible cultivar because it is grown in both the mid-Atlantic and southeastern regions.

In South Carolina, rye (32 lb/ acre), Cahaba vetch ( $66 \mathrm{lb} /$ acre), and hairy vetch ( $79 \mathrm{lb} /$ acre) were seeded on 10 October 2006 and 15 October 2007. Whole plots were $100 \mathrm{ft}$ long and $12 \mathrm{ft}$ wide. On 7 March 2007 and 29 February 2008, cover crops were flattened with a metal roller (Fig. 1A) and sprayed with paraquat (Gramoxone, 3 pt/ acre) (Fig. 1B) $(18,19)$. Prior to rolling, aboveground biomass was collected from two $0.25-\mathrm{m}^{2}$ areas within each plot, dried for $24 \mathrm{~h}$ at $70^{\circ} \mathrm{C}$, and weighed. In both years plots were disked three times one week apart by whole plot treatment (Fig. 1C); the disk was power washed with water between treatments. Fertilizer (500 lb/ acre 10-10-10) was applied to all plots in March 2007. In March 2008 plant-available nitrogen was calculated as $2.15 \%$ of the dry weight of the vetch biomass [(4); Zhou and Everts, unpublished)]. No fertilizer was applied to vetch plots, whereas rye plots received $500 \mathrm{lb} /$ acre 10-10-10. Plots were covered with black polyethylene mulch on 29 March 2007 and 26 March 2008. Watermelons were seeded in a greenhouse on 15 March 2007 and 1 April 2008. Seedlings were transplanted 36 
inches apart within rows on 10 April 2007 and 2 May 2008. Subplots were $45 \mathrm{ft}$ long and one and two rows wide in 2007 and 2008, respectively (Fig. 1D), which was equivalent to 1210 and 2420 plants per acre, respectively. The pollenizer 'SP4,' highly resistant to Fusarium wilt race 1, was inter-transplanted between every fourth seedless watermelon plant within each row in both years. For preemergence weed control, ethalfuralin + clomazone (Strategy $6 \mathrm{pt} / \mathrm{acre}$ ) was applied between rows. Foliar diseases were managed in 2007 with two applications each of chlorothalonil (Bravo Weather Stik, 3 pt/acre) and boscalid + pyraclostrobin (Pristine 38WG, 18.5 oz/ acre) and one application of myclobutanil (Rally, 2.5 oz/ acre). In 2008 quinoxyfen (Quintec, 6 fl oz/ acre) was applied once. Insects were managed in 2007 with two applications of imidacloprid (Provado, $3.5 \mathrm{fl} \mathrm{oz/acre)} \mathrm{and} \mathrm{one} \mathrm{application} \mathrm{of} \mathrm{methomyl}$ (Lannate, $0.5 \mathrm{lb} / \mathrm{acre}$ ). In 2008, bifenthrin (Sniper, $6.4 \mathrm{fl}$ oz/ acre), methomyl (Lannate, $0.5 \mathrm{lb} /$ acre) and esfenvalerate (Asana $9.6 \mathrm{fl} \mathrm{oz} /$ acre) were applied. Drip fertigation with $8 \mathrm{~N}-0 \mathrm{P}-8 \mathrm{~K}$ plus minor elements was applied daily beginning 1 week after transplanting. The $\mathrm{N}$ and $\mathrm{K}$ rates changed with growth stage: $7 \mathrm{lb} \mathrm{N}$ and K per week from transplant to blossom, $10.5 \mathrm{lb} \mathrm{N}$ and K per week from blossom to fruit set, $14 \mathrm{lb} \mathrm{N}$ and K per week from fruit set to first harvest, and $10.5 \mathrm{lb} \mathrm{lb} \mathrm{N}$ and K per week after first harvest. The percent of plants showing symptoms of Fusarium wilt (Fig. $1 \mathrm{E}, \mathrm{F}$ ) was assessed weekly in both years beginning 14 May through 25J une. Marketable fruit was harvested, counted, and weighed on 21J une, 29 J une, and $6 \mathrm{~J}$ uly 2007 and 18 J une, 27 June, and 10 July 2008.

In Maryland, rye (140 lb/ acre) and 'Cahaba White' and hairy vetch (30 $\mathrm{lb} /$ acre in 2007, $45 \mathrm{lb}$ /acre in 2008) were seeded on 10 October 2006 and 18 October 2007. Rates were based on local practices. Plots were disked on 9 and 16 May 2007 and 22 and 28 May 2008. The amount of fertilizer applied was adjusted based on the amount of nitrogen calculated from the vetch biomass. In 2007, $750 \mathrm{lb}$ / acre 16-0-18 was applied to rye plots and 456 and $575 \mathrm{lb} /$ acre $16-$ 0-18 was applied to 'Cahaba White' and hairy vetch plots, respectively. An additional 294 and $175 \mathrm{lb} /$ acre 0-0-18 was applied to 'Cahaba White' and hairy vetch plots, respectively, so that all treatments received the same amount of potassium. In 2008, $750 \mathrm{lb} /$ acre of 16-0-18 was applied to rye plots and 17 and $115 \mathrm{lb} /$ acre of 16-0-18 was applied to 'Cahaba White' and hairy vetch plots, respectively. In addition, $750 \mathrm{lb} /$ acre $0-0-18$ was applied to both vetch plots. Plots were $64 \mathrm{ft}$ long and one row wide and covered with black polyethylene mulch under which a drip irrigation tube was laid. Watermelons were seeded in the greenhouse on 2 May 2007 and 2 May 2008 and transplanted to the field on 30 May 2007 and 3 J une 2008. Seedlings were spaced 36 inches apart within rows, which was equivalent to 2420 plants per acre. The pollenizer 'SP4' was inter-transplanted between every other seedless watermelon plant within each row in both years. Ethalfluralin (Curbit 3E, 2 pt/ acre) and terbacil (Sinbar WP, 3 $\mathrm{oz} / \mathrm{acre}$ ) were applied for pre-emergence weed control. Foliar diseases were managed with chlorothalonil (Bravo Weather Stik, 2 pt/ acre) and boscalid + pyraclostrobin (Pristine 38WG, 15 oz/ acre) applied on alternate weeks in both years from the end of J une until harvest. The percent of plants showing symptoms of Fusarium wilt was assessed weekly from 2 to 7 weeks after transplanting. All fruit were harvested and weighed on 13 August 2007 and 7 August 2008. Marketable sized fruit were defined as those weighing between 9 and 24 pounds apiece.

Data analysis was done with PROC MIXED (version 9.1, SAS Institute Inc., Cary, NC). Year, location, cover crop, and cultivar were considered fixed variables and block-by-cover crop was used as the random variable. In preliminary analyses, there was a significant $(\mathrm{P}<0.05)$ year-by-location-bycultivar interaction for wilt incidence and significant year-by-cultivar and location-by-cultivar interactions for marketable weight. Thus, data were analyzed by year and location. There were no cover crop-by-cultivar interactions. 


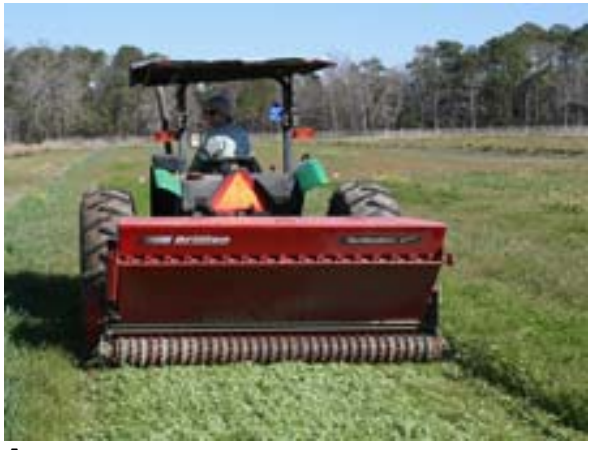

$\mathbf{A}$
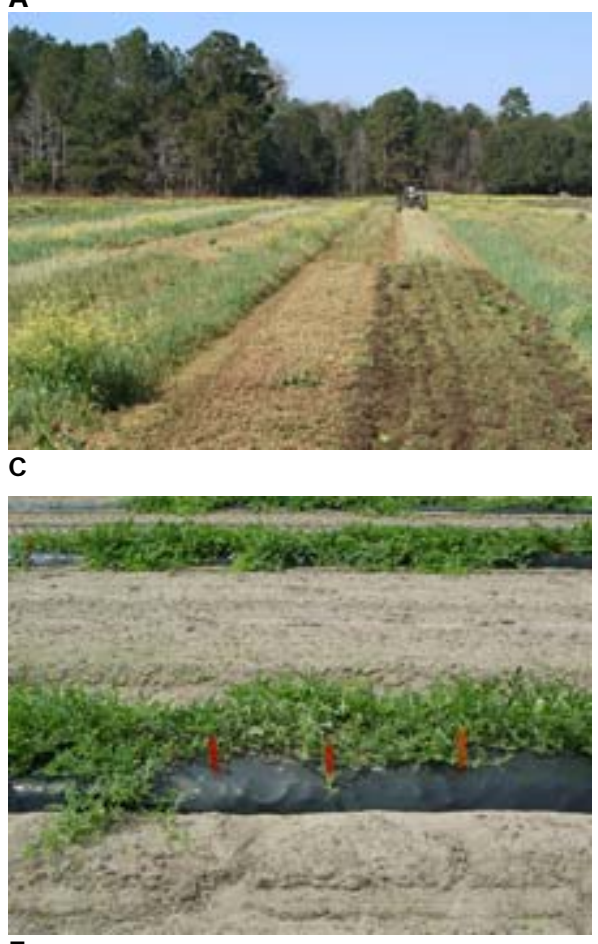

$\mathbf{E}$

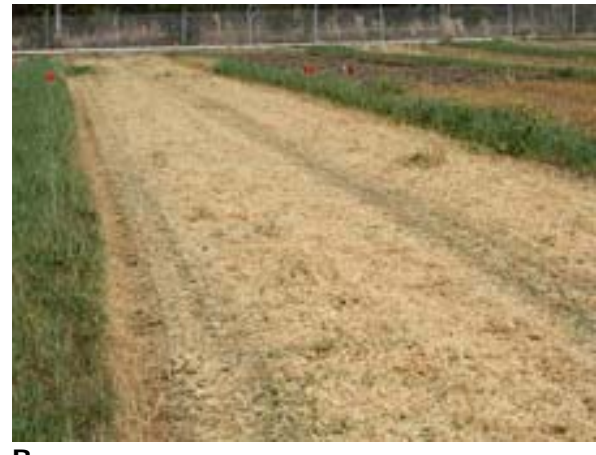

B
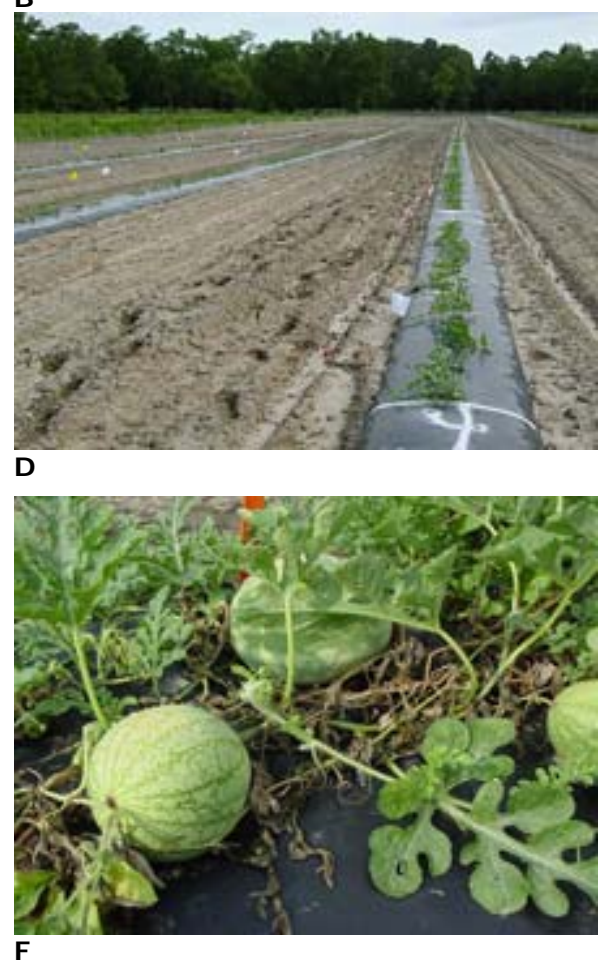

Fig. 1. (A) In the spring, cover crops were rolled. (B) Cover crops were killed with contact herbicide. (C) Cover crops were disked two to three times to incorporate. (D) Single-row plots were used in South Carolina, 2007. (E) Symptomatic plants were counted and marked weekly. (F) Some vines were killed by Fusarium before harvest.

\section{Effects of Cover Crops and Cultivar Resistance on Fusarium Wilt and Yield}

Fusarium wilt incidence. In Maryland in both years, incidence of Fusarium wilt symptoms on seedless watermelon plants was lower in plots seeded to either vetch crop than in plots seeded to rye the preceding fall (Table 1). 'Cahaba White' vetch and hairy vetch were equally effective. In South Carolina, 'Cahaba White' vetch reduced incidence of Fusarium wilt in 2007, while hairy vetch did not reduce incidence significantly. Wilt incidence was too low in South Carolina in 2008 to detect differences among cover crops.

In all four experiments, 'Revolution,' the seedless watermelon cultivar moderately resistant to race 1, had a much lower wilt incidence than 'Sugar Heart,' the susceptible cultivar. For both locations, the difference in wilt incidence between cultivars was greater in 2008 than in 2007. 
Table 1. Final Fusarium wilt incidence (\%) in plots naturally infested with FON races 1 and 2 in South Carolina and Maryland in 2007 and 2008.

\begin{tabular}{|l|l|c|c|c|c|c|}
\hline \multirow{2}{*}{\multicolumn{2}{|c|}{ Treatment }} & \multicolumn{2}{|c|}{ South Carolina } & \multicolumn{3}{|c|}{ Maryland } \\
\cline { 2 - 7 } & $\mathbf{2 0 0 7}$ & $\mathbf{2 0 0 8}$ & $\mathbf{2 0 0 7}$ & $\mathbf{2 0 0 8}$ & Combined \\
\hline $\begin{array}{l}\text { Cover } \\
\text { crop }\end{array}$ & Rye (control) & $64 \mathrm{a}^{\mathrm{x}}$ & $2.4 \mathrm{a}$ & $52 \mathrm{a}$ & $69 \mathrm{a}$ & $60.9 \mathrm{a}$ \\
\cline { 2 - 7 } & Hairy vetch & $52 \mathrm{ab}$ & $2.3 \mathrm{a}$ & $35 \mathrm{~b}$ & $39 \mathrm{~b}$ & $36.7 \mathrm{~b}$ \\
\cline { 2 - 7 } & Cahaba White' vetch & $47 \mathrm{~b}$ & $1.0 \mathrm{a}$ & $38 \mathrm{~b}$ & $43 \mathrm{~b}$ & $40.7 \mathrm{~b}$ \\
\cline { 2 - 7 } & P value & 0.05 & NS & 0.01 & 0.01 & 0.0001 \\
\hline \multirow{3}{*}{ Cultivar } & Sugar Heart (susceptible) & $73 \mathrm{~A}$ & $4.2 \mathrm{~A}$ & $56 \mathrm{~A}$ & $79 \mathrm{~A}$ & $-\mathrm{y}$ \\
\cline { 2 - 7 } & $\begin{array}{l}\text { Revolution (moderately } \\
\text { resistant to race 1) }\end{array}$ & $35 \mathrm{~B}$ & $0.4 \mathrm{~B}$ & $29 \mathrm{~B}$ & $21 \mathrm{~B}$ & - \\
\cline { 2 - 7 } & P value & 0.0001 & 0.01 & 0.0001 & 0.0001 & \\
\hline
\end{tabular}

$x$ Means within a column with the same lowercase or uppercase letters are not significantly different based on t tests of least-squares means.

$y$ Cultivar-by-year interaction was $P=0.004$ for South Carolina and $P<0.0001$ for Maryland.

Marketable yield. Cover crop treatments did not significantly affect total weight or weight of marketable-sized fruit in any experiment (Tables 2 and 3). Thus, the different fertilizer applications in the different cover crop treatments also had no effects on yields. Number of marketable-sized fruit also did not differ among cover crops (data not shown). Yields were greater in South Carolina than in Maryland, because in South Carolina all fruit were allowed to reach marketable size before harvest, whereas in Maryland all fruit were harvested at one time.

In three experiments, fruit weights produced by moderately resistant cultivar 'Revolution' were much greater than weights of susceptible cultivar 'Sugar Heart' (Table 2 and 3). In South Carolina in 2007, up to half of the 'Sugar Heart' fruit were unmarketable because of sunburn on exposed fruit where vines had died (data not shown). In general, the distribution of fruit among different size categories was not influenced by cover crop or cultivar (data not shown). The year-by-cultivar and location-by-cultivar interactions were significant because in the 2008 experiment in South Carolina, wilt incidence was so low there was no difference between the two cultivars (Table 2).

Table 2. Weight (tons/acre) of marketable-size and all sizes of watermelon fruit from plots naturally infested with FON races 1 and 2 in South Carolina.

\begin{tabular}{|l|l|c|c|c|c|}
\hline \multirow{2}{*}{\multicolumn{2}{|c|}{ Treatment }} & \multicolumn{2}{|c|}{2007} & \multicolumn{2}{c|}{2008} \\
\cline { 2 - 6 } & Marketable & Total & Marketable & Total \\
\hline \multirow{2}{*}{$\begin{array}{l}\text { Cover } \\
\text { crop }\end{array}$} & Rye (control) & 9.5 & 13.6 & 11.2 & 24.1 \\
\cline { 2 - 6 } & Hairy vetch & 12.1 & 17.1 & 11.3 & 20.4 \\
\cline { 2 - 6 } & Cahaba White' vetch & 11.6 & 16.8 & 13.1 & 21.6 \\
\hline \multirow{2}{*}{ Cultivar } & Sugar Heart (susceptible) & $7.3 \mathrm{~B}^{\mathrm{x}}$ & $13.2 \mathrm{~B}$ & 12.3 & 22.7 \\
\cline { 2 - 6 } & $\begin{array}{l}\text { Revolution (moderately } \\
\text { resistant to race 1) }\end{array}$ & $14.8 \mathrm{~A}$ & $18.4 \mathrm{~A}$ & 11.5 & 21.3 \\
\hline
\end{tabular}

$x$ Means within a column with the same letters are not significantly different based on t tests of least-squares means, $\mathrm{P}<0.01$ in 2007 for cultivars. Cultivar-byyear interaction was $P=0.003$. 
Table 3. Weight (tons/acre) of marketable-size and all sizes of watermelon fruit from plots naturally infested with FON races 1 and 2 in Maryland.

\begin{tabular}{|l|l|c|c|c|c|}
\hline \multirow{2}{*}{\multicolumn{2}{|c|}{ Treatment }} & \multicolumn{2}{|c|}{2007} & \multicolumn{2}{c|}{2008} \\
\cline { 2 - 6 } & Marketable & Total & Marketable & Total \\
\hline \multirow{2}{*}{$\begin{array}{l}\text { Cover } \\
\text { crop }\end{array}$} & Rye (control) & 4.4 & 10.6 & 9.6 & 12.7 \\
\cline { 2 - 6 } & Hairy vetch & 6.7 & 12.4 & 12.7 & 16.1 \\
\cline { 2 - 6 } & Cahaba White' vetch & 6.1 & 11.1 & 12.3 & 15.9 \\
\hline Cultivar & Sugar Heart (susceptible) & $1.0 \mathrm{~B}$ & $6.8 \mathrm{~B}$ & $7.5 \mathrm{~B}$ & $10.1 \mathrm{~B}$ \\
\cline { 2 - 6 } & $\begin{array}{l}\text { Revolution (moderately } \\
\text { resistant to race 1) }\end{array}$ & $10.5 \mathrm{~A}$ & $16.0 \mathrm{~A}$ & $15.6 \mathrm{~A}$ & $19.7 \mathrm{~A}$ \\
\hline
\end{tabular}

$x$ Means within a column with the same letters are not significantly different based on t tests of least-squares means $P<0.0001$ in 2007 and $P<0.001$ in 2008 for total yields and $P \leq 0.0001$ for yield of marketable-size fruit. There were no interactions by year.

Vetch biomass. In South Carolina, aboveground biomass of vetch measured in the spring was greater than the biomass of rye in both years, probably because vetches were seeded at a higher rate than rye was (Table 4). Biomass of the two vetches did not differ significantly, although the stand of hairy vetch, 16.6 plants/ $\mathrm{ft}^{2}$, was greater $(\mathrm{P}<0.0001)$ than the stand of 'Cahaba White' vetch, 11.4 plants/ $\mathrm{ft}^{2}$, in both years at 3 weeks after emergence. Although rye was seeded in Maryland at a higher rate than vetches were, biomass of 'Cahaba White' vetch was greater than the biomass of the other two cover crops in 2007; biomass did not differ among cover crops in Maryland in 2008. Vetches produced approximately the same amount of biomass in both locations in 2008 even though the seeding rate was $60 \%$ higher and the growth period was 2 months shorter in South Carolina than in Maryland.

Table 4. Aboveground biomass (tons/acre) of cover crops incorporated into field plots prior to transplanting seedless watermelon.

\begin{tabular}{|l|c|c|c|}
\hline \multirow{2}{*}{ Cover crop } & South Carolina & \multicolumn{2}{|c|}{ Maryland $^{\mathrm{y}}$} \\
\cline { 2 - 4 } & $\mathbf{2 0 0 7 - 2 0 0 8}$ & $\mathbf{2 0 0 7}$ & $\mathbf{2 0 0 8}$ \\
\hline Rye (control) & $1.08 \mathrm{~b}^{\mathrm{z}}$ & $0.45 \mathrm{~b}$ & 1.90 \\
\hline Hairy vetch & $2.13 \mathrm{a}$ & $0.55 \mathrm{~b}$ & 1.67 \\
\hline Cahaba White' vetch & $2.12 \mathrm{a}$ & $1.00 \mathrm{a}$ & 2.43 \\
\hline P value & $<0.0001$ & 0.002 & 0.58 \\
\hline
\end{tabular}

x Rye (32 lb/acre), Cahaba vetch (66 lb/acre), and hairy vetch (79 lb/acre) were seeded on 10 October 2006 and 15 October 2007. Biomass was collected prior to rolling on 7 March 2007 and 29 February 2008.

Y Rye (140 lb/acre) and 'Cahaba White' and hairy vetch (30 lb/acre in 2007, 45 $\mathrm{lb} /$ acre in 2008) were seeded on 10 October 2006 and 18 October 2007. Biomass was collected prior to disking on 9 May 2007 and 22 May 2008.

$\mathrm{z}$ Means within a column with the same letters are not significantly different based on t tests of least-squares means at $P<0.01$.

Economic analysis of cover crops. Treatment-specific costs were cover crop seed and pre-plant fertilizer. Based on actual costs for these experiments, vetch seed was slightly more expensive than rye seed, although this cost was partially offset by reducing the rate of nitrogen fertilizer applied to fields cropped to vetch, because of the organic nitrogen supplied by the vetch cover crop. We calculated that the vetches contributed on average $81 \pm 29 \mathrm{lb} /$ acre of nitrogen in these experiments. Costs of the vetch treatments were higher than the standard rye treatment in South Carolina, because vetch was seeded at a higher rate than that used for vetch in Maryland (Table 5). 
The variable production cost (which included supplies, labor, and interest on operating capital) for drip-irrigated, seedless watermelon with polyethylene mulch was \$2696/ acre (excluding pre-plant, in-bed fertilizer, which was a treatment cost in these experiments) $(1,6)$. Based on a total production cost of \$3125 (which included estimates for machinery, permanent irrigation fixtures, land rent, and overhead), a grower of 'Sugar Heart' would have lost more money growing a rye cover crop instead of vetch in a heavily infested field in Maryland. It is noted that gross revenue in Maryland would be higher with multiple harvests. Net returns averaged across cultivars and locations were very similar for the two vetches (Table 5). Averaged across the two vetches, two locations, and two years, a vetch cover crop increased a grower's net return by $\$ 799 /$ acre over a rye cover crop.

Table 5. Costs and returns (\$) for cover crop treatments in South Carolina and Maryland averaged across 2007 and 2008.

\begin{tabular}{|l|r|r|r|r|r|r|}
\hline \multirow{2}{*}{ Cost } & \multicolumn{2}{|c|}{ South Carolina } & \multicolumn{3}{c|}{ Maryland } \\
\cline { 2 - 7 } & Rye & $\begin{array}{r}\text { Hairy } \\
\text { vetch }\end{array}$ & $\begin{array}{r}\text { Cahaba } \\
\text { White' } \\
\text { vetch }\end{array}$ & \multicolumn{1}{c|}{ Rye } & $\begin{array}{r}\text { Hairy } \\
\text { vetch }\end{array}$ & $\begin{array}{c}\text { 'Cahaba } \\
\text { White' } \\
\text { vetch }\end{array}$ \\
\hline Cover crop seed & 11 & 155 & 129 & 48 & 74 & 74 \\
\hline Fertilizer & 115 & 58 & 58 & 191 & 169 & 153 \\
\hline Subtotal treatment costs & 126 & 212 & 187 & 239 & 243 & 226 \\
\hline Other direct costs & 3125 & 3125 & 3125 & 3125 & 3125 & 3125 \\
\hline $\begin{array}{l}\text { Gross revenue across } \\
\text { cultivars }\end{array}$ & 4,140 & 4,680 & 4,940 & 2,800 & 3,880 & 3,680 \\
\hline Net return with Revolution & 1,093 & 2,496 & 2,293 & 1,471 & 2,600 & 2,267 \\
\hline $\begin{array}{l}\text { Net return with Sugar } \\
\text { Heart }\end{array}$ & 688 & 232 & 986 & $(2,302)$ & $(1,173)$ & $(1,236)$ \\
\hline Net return across cultivars & 889 & 1,360 & 1,646 & $(564)$ & 512 & 329 \\
\hline $\begin{array}{l}\text { Return above rye for } \\
\text { Revolution }\end{array}$ & - & 1,403 & 1,200 & - & 1,129 & 796 \\
\hline $\begin{array}{l}\text { Return above rye for } \\
\text { Sugar Heart }\end{array}$ & - & $(456)$ & 298 & - & $1,129 z$ & $1,067^{z}$ \\
\hline $\begin{array}{l}\text { Return above rye across } \\
\text { Cultivars }\end{array}$ & - & 471 & 757 & - & 1,076 & 893 \\
\hline $\begin{array}{l}\text { Return above rye across } \\
\text { locations for Revolution }\end{array}$ & - & 1,266 & 998 & - & - & - \\
\hline $\begin{array}{l}\text { Return above rye across } \\
\text { locations for Sugar Heart }\end{array}$ & - & $336^{z}$ & $682^{z}$ & - & - & - \\
\hline $\begin{array}{l}\text { Return above rye across } \\
\text { locations and cultivars }\end{array}$ & - & 774 & 825 & - & - & - \\
\hline
\end{tabular}

$x$ Direct costs of production include variable costs (excluding in-bed fertilizer) of $\$ 2696$ and fixed and other costs of $\$ 429$ (1).

y Marketable weight of fruit at $\$ 0.20 / \mathrm{lb}$.

$\mathrm{z}$ Represents revenue not lost.

\section{Conclusions and Recommendations}

'Cahaba White' vetch was as effective as hairy vetch in reducing incidence of Fusarium wilt with a susceptible seedless watermelon cultivar and a cultivar with resistance to race 1. As in a previous study in Maryland, there were no interactions between cover crop and cultivar treatments (19). In the current study, vetch cover crops reduced wilt incidence by approximately the same degree with the susceptible as with the moderately resistant cultivar. This result differed from previous work in Maryland, where wilt suppression was greater for a moderately resistant than a susceptible cultivar (21). Biomass produced by 'Cahaba White' vetch was equivalent to or greater than biomass produced by 
hairy vetch, even though hairy vetch had a higher plant stand than 'Cahaba White' vetch in South Carolina. Thus, 'Cahaba White' hybrid common vetch is another vetch, in addition to hairy vetch, that can be used by watermelon growers in the mid-Atlantic and southeastern United States to mitigate the effects of Fusarium wilt. Although the mechanism of the suppression is unknown, previous work demonstrated a correlation between populations of soil bacteria and wilt reduction (21).

The moderately resistant cultivar Revolution' yielded more marketable-sized fruit and more total fruit than the susceptible cultivar 'Sugar Heart' in three of four experiments with significant levels of Fusarium wilt present. Triploid cultivars that have resistance only to race 1 of FON increase yield even when grown in fields infested with a mixture of races 1 and 2, as reported previously (19). The economic benefits of vetch cover crops were numerically greater with the moderately resistant cultivar than with the susceptible cultivar. Thus, vetch cover crops can benefit watermelon growers, regardless of the cultivar grown. In South Carolina, one large watermelon grower planted 50 and 150 acres of hairy vetch in 2007 and 2008, respectively [(10); Keinath, unpublished].

\section{Acknowledgments}

Funding for this project was provided by NIFA/ USDA in the form of a Pest Management Alternatives Program grant to the University of Maryland (200634381-16955). Additional funding was provided by CSREES/ USDA under project numbers SC-1700161 and 2006-34287-17370 and by the South Carolina Watermelon Association. Technical assistance was provided by Ginny DuBose, Andy Lassiter, and Greg Baccari. Advice on statistical analysis was provided by Denis Shah.

Technical contribution no. 5815 of the Clemson University Experiment Station.

\section{Literature Cited}

1. Anon. 2008. Enterprise Budgets: Watermelons - on plastic- drip irrigation seedless. Online. Clemson Cooperative Extension, Department of Applied Economics and Statistics.

2. Averre, C., Schoulteis, J., and Westerbeek, P. J. 1993. Watermelon Fusarium wilt evaluation. Biol. Cult. Tests 8:35.

3. Bruton, B. D., Fish, W. W., and Langston, D. B. 2008. First report of Fusarium wilt caused by Fusarium oxysporum f. sp. niveum race 2 in Georgia watermelons. Plant Dis. 92:983.

4. Clark, A. 2007. Managing Cover Crops Profitably, 3rd Edn. Sustainable Agriculture Network, Beltsville, MD.

5. Egel, D. S., Harikrishnan, R., and Martyn, R. 2005. First report of Fusarium oxysporum f. sp. niveum race 2 as causal agent of Fusarium wilt of watermelon in Indiana. Plant Dis. 89:108.

6. Estes, E. A., Skroch, W. A., Konsler, T. R., Shoemaker, P. B., and Sorensen, K. A. 1985. Net economic values of eight soil management practices used in stake tomato production. J . Amer. Soc. Hort. Sci. 110:812-816.

7. Gallaher, R. N., Dickson, D. W., Corella, J. F., and Hewlett, T. E. 1988. Tillage and multiple cropping systems and population dynamics of phytopararsitic nematodes. Ann. Appl. Nematol. 2:90-94.

8. Hopkins, D. L., Lobinske, R. J., and Larkin, R. P. 1992. Selection for Fusarium oxysporum $\mathrm{f}$. sp. niveum race 2 in monocultures of watermelon resistant to Fusarium wilt. Phytopathology 82:290-293.

9. Keinath, A. P., and DuBose, V. B. 2009. First report of Fusarium oxysporum f. sp. niveum race 2 in South Carolina watermelon fields. (Abstr.) Phytopathology 99:S63.

10. Keinath, A. P., and Hassell, R. L. 2009. On-farm evaluation of hairy vetch and fumigation for integrated control of Fusarium wilt on seedless watermelon. Plant Disease Management Reports 3:V035. Online publication. doi:10.1094/ PDMR03.

11. Keinath, A. P., Hassell, R. L., and DuBose, V. B. 2006. Evaluation of mini and pollenizer watermelons for susceptibility to Fusarium wilt, powdery mildew, and gummy stem blight, 2005. Online publication. Biological and Cultural Tests for Control of Plant Diseases 21:V002. Online publication. doi:10.1094/BC21. 
12. Martyn, R. D., and Bruton, B. B. 1989. An initial survey of the United States for races of Fusarium oxysporum f. sp. niveum. HortScience 24:696-698.

13. Orton, W. A., and Meier, F. C. 1922. Diseases of Watermelons. USDA Farmers' Bull. No. 1277. Washington, DC.

14. Sumner, D. R., and Hall, M. R. 1994. Resistance of watermelon cultivars to Fusarium wilt. Biol. Cult. Tests 9:53.

15. Timper, P., Davis, R. F., and Tillman, P. G. 2006. Reproduction of Meloidogyne incognita on winter cover crops used in cotton production. J . Nematol. 38:83-89.

16. Whalen, J. 1999. Crop Profile for Watermelons in Maryland. Online. Natl. Info. System for the Regional IPM Centers, North Carolina State Univ., Raleigh, NC.

17. Zhou, X. G., and Everts, K. L. 2003. Races and inoculum density of Fusarium oxysporum f. sp. niveum in commercial watermelon fields in Maryland and Delaware. Plant Dis. 87:692-698.

18. Zhou, X. G., and Everts, K. L. 2004. Suppression of Fusarium wilt of watermelon by soil amendment with hairy vetch. Plant Dis. 88:1357-1365.

19. Zhou, X. G., and Everts, K. L. 2006. Suppression of Fusarium wilt of watermelon enhanced by hairy vetch green manure and partial cultivar resistance. Online. Plant Health Progress DOI:10.1094/ PHP-2006-0405-01-RS.

20. Zhou, X. G., and Everts, K. L. 2006. Resistance to Fusarium wilt in triploid watermelon cultivars, 2005. Online publication. Biological and Cultural Tests for Control of Plant Diseases 21:V003. Online publication. doi:10.1094/BC21.

21. Zhou, X. G., and Everts, K. L. 2007. Effects of host resistance and inoculum density on the suppression of Fusarium wilt of watermelon induced by hairy vetch. Plant Dis. 91:92-96.

22. Zhou, X. G., Everts, K. L., and Bruton, B. D. 2010. Race 3, a new and highly virulent race of Fusarium oxysporum f. sp. niveum causing Fusarium wilt in watermelon. Plant Dis. 94:92-98. 